\title{
EXPERIMENTAL VERIFICATION OF TWO COMPONENT IMPLANT OPTIMIZATION RESULTS IN CONTEXT OF FATIGUE LIFE
}

\section{WERYFIKACJA EKSPERYMENTALNA WYTRZYMAŁOŚCI ZMĘCZENIOWEJ ZOPTY- MALIZOWANEGO IMPLANTU STOMATOLOGICZNEGO*}

\begin{abstract}
In this paper the verification of the optimal dental implant design is presented. It is focused on fatigue fracture and is carried out with experimental tests. The optimal design was obtained with an optimization strategy using finite element model and genetic algorithm hybridized with Hooke-Jeeves technique. The fatigue tests of the prototype and initial designs of dental implants have been performed on Instron 8874 testing system using Locati method of an accelerated fatigue testing. The presented studies are excepted to verified the effectiveness of optimization strategy. Due to used methodology for experimental verification only qualitative effects of the optimization are compared. The work is a part of long term project under the grant R130020 06 "Development and preparation of dental implant prototypes".
\end{abstract}

Keywords: dental implant, optimization, fatigue, experimental fatigue test.

\begin{abstract}
W artykule przedstawiono weryfikację zoptymalizowanego implantu zębowego w kontekście wytrzymałości zmęczeniowej przy pomocy testów laboratoryjnych. Optymalne rozwiąanie otrzymano przy zastosowaniu modelu numerycznego metoda elementów skończonych oraz strategii tączacej algorytm genetyczny z procedura Hooke-Jeeves. Dla projektu bazowego oraz ulepszonego rozwiązania przeprowadzono serię testów na maszynie Instron 8874 używając metody Locati przyśsieszonego badania zmęczeniowego. Prezentowane badania sa weryfikacją efektywności przyjętej strategii optymalizacji. Z powodu zastosowanej metodologii badań eksperymentalnych, efekty optymalizacji poddano tylko porównaniu jakościowemu.
\end{abstract}

Stowa kluczowe: implant zębowy, optymalizacja, wytrzymatość zmęczeniowa, testy eksperymentalne wytrzymatości zmęczeniowej.

\section{Introduction}

Dental implant is expected to be serviced as long as it is able to fulfill biological, esthetical and functional requirements. There is no service life for any of its components considered. Therefore, the proper design should based on the assumption that the implant service life has to be longer than the maximal patients' life expectancy regardless of biological and biomechanical conditions.

According to the retrospective studies $[12,26,30]$ one of the problems reported in long term service of the implants is fatigue failure. Systematic review of twentysix followup studies estimated a cumulative incidence of implant fractures after 5 years on the level of $0.14 \%$ [22]. However, the fracture ratio for the followup studies for up to 15 years [2] rises drastically and can reach even $16 \%$ in the maxilla. Dental implant failure usually results in an expensive, long term therapy often accompanied by the patient's trauma. It makes the fatigue resistance crucial feature to be include in implant designing. The significant rise in fatigue fracture cases after 5 years, which the followup studies are mostly limited to, can suggest that this period is inadequate to examine this phenomenon. Additionally, it should be taken into account that nowadays, market competition and patients' demands force the producers to introduce the new or modified design in very short design cycles. Therefore, there is the need to develop of the efficient procedure for fatigue fracture risk minimization.

Many researchers undertake the implant failure problem using laboratory tests $[7,9,10,11,13,20,23,27,29,31,32]$ and numerical approach [17]. Among the others, special attention should be paid to the studies done by Wierszycki [38] and Ilies [20]. Wierszycki proposed complete methodology and computational model for fatigue fracture estimation using strain based approach. The results were supported with clinical observations [39]. Ilies, on the other hand, proposed approach for fatigue estimation utilizing stresses and provided additional verification with laboratory tests. Another important work was done by Patterson and Johns [28] who presented the concept of fatigue resistance as a function of screw preload. These results prove the existence of the optimal value of screw preload in context of fatigue life of the implant screw. Finally, Genna $[18,19]$ utilized shakedown analysis to examine lowcycle fatigue failure of dental implants. The results show that the 'worst' load case in context of fatigue fracture is characterized by pure transversal load or its strong domination on axial load.This conclusion was also confirmed for the prototype analyzed in the presented study by Szajek [35].

Taking into account the results of the above mentioned studies, the complete designing methodology for improvement of two

(*) Tekst artykułu w polskiej wersji językowej dostępny w elektronicznym wydaniu kwartalnika na stronie www.ein.org.pl 
component dental implant fatigue life was proposed [33]. The procedure utilizes optimization techniques (genetic algorithm hybridized with Hooke-Jeeves technique) to find the optimal configuration of geometry parameters and screw preload considering static failure risk and adequate levels of screw loosening/tightening moments. Moreover, the simplified computational model, yet, capable to estimate all necessary dental implant features is thoroughly described. The procedure was used to optimize the representative design of a two component implant.

In the presented work the effectiveness of the proposed optimization strategy is verified with experimental tests. The fatigue tests of the prototype and initial design have been carried out using Locati method of an accelerated fatigue testing. The used method has been successfully applied to quality control fatigue tests of glass fibre reinforced plastics [5], metallic materials and components [9] and research using thermography [25]. In order to carry out the tests, the simplified prototype (Fig. 2) was manufactured by Osteoplant. Due to used methodology, only qualitative effects are compared.

The paper is structured as follows. Section 2 recalls the most important information on the optimization done and the final design while section 3 presents methodology and the results of laboratory tests of dental implant fatigue life.

\section{Two-component implant optimization}

The goal of the optimization is to find a combination of geometry parameters for which the optimal screw preload maximizes the number of cycles to failure which is measured in indirect way based on normalized maximal effective stress amplitude at zero mean stress (explanation below in the text). Additionally, it has to be taken into account that changes cannot reduce the loosening moment $(L)$ below safe limit of $150 \mathrm{Nmm}$ (the value for the initial design ${ }^{1}$ ), the tightening moment $(T)$ should be applicable considering bone implant interface resistance (300Nmm limit is assumed) and plastic strains $(S)$ cannot occur during tightening and bending. Finally, the problem is formulated as follows:

$$
\max _{x \in X} \sigma_{\text {ar }}^{\prime}(x)
$$

Subject to: $S(x) \leq 1.0$;

$$
L(x) \geq 150 \mathrm{Nmm}
$$$$
T(x) \leq 300 \mathrm{Nmm}
$$

where $x$ denotes design parameters (see Fig. 1a, parameter B is omitted in this study).

Finite Element Model (FEM) was developed in order to compute the objective and constraints for various configuration of parameters [33]. The geometry is simplified to axisymmetric, however, the special type of finite elements is used, which enables to describe nonlinear asymmetric deformation due to asymmetric loads [1]. All components of an implant are made of medical alloys of titanium. The fixture of the implant is made of medical titanium (Grade IV) while the abutment and the screw of its alloys (Ti-6Al-4V-ELI). The isotropic, non-linear elastic-plastic characteristics of material models

\footnotetext{
1 Friction between screw head and interior cylinder of an abutment is not considered. It was estimated [29] that an additional moment due to omitted friction forces can oscillate from 0 to $50 \mathrm{Nmm}$.
}
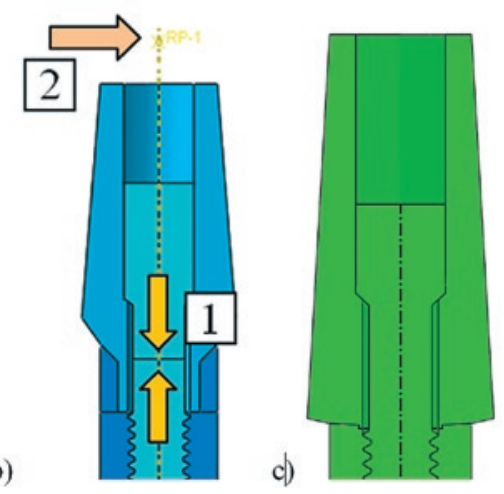

\begin{tabular}{|l|c|c|}
\hline Param. & Initial & Optim. \\
\hline A [mm] & 1.05 & 1.11 \\
\hline C [deg] & 31 & 42.7 \\
\hline D [mm] & 3.45 & 2.2 \\
\hline E [-] & 0.356 & 0.12 \\
\hline F [mm] & 1.5 & 0.1 \\
\hline G [deg] & 45 & 87.1 \\
\hline P [N] & 425 & 520.0 \\
\hline
\end{tabular}

d) 
convergence problems) and there are relatively big number of design parameters, genetic algorithm (GA) is proposed. Binary encoding with short chromosomes is used (4 to 6 bit per design parameter) which convert the problem to combinatorial one were GA is very effective [17]. The sufficient accuracy of the optimal solution is provided by hybridization with Hooke-Jeeves procedure [16] (HJ) which starts from the best point found with GA after 10 generations. To prevent additional multimodality Gray encoding is used $[3,6]$. The static, exterior penalty approach is used in order to control the constraints. The optimization procedure along with FE model rebuilding has been implemented as an independent module in Abaqus/CAE environment [34].

The optimization process was carried out three times. The best solution is presented in Fig. 1c. The objective function is reduced by $95 \%$ to 0.0197 what is an equivalent of $4.5 \mathrm{e} 17$ cycles to fatigue fracture. All constraints features are below assumed limit and equals 0.49 , $217 \mathrm{Nmm}$ and $285 \mathrm{Nmm}$ for static risk factor, loosening and tightening moment, respectively.

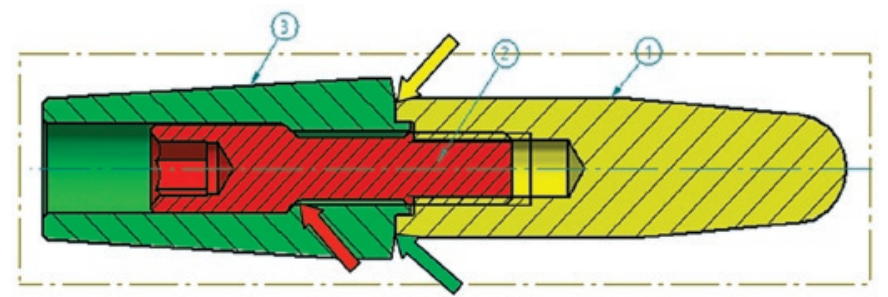

Fig. 2. Prototype geometry: (1) fixture, (2) screw, (3) abutment. Arrows indicates the point where fatigue crack are the most likely to appear for particular components (more in the text; colors agree with component section colors).

\section{Material and methods}

To verify the optimization result the fatigue tests of the optimal and initial designs have been carried out. The two series of dental implants are produced: initial design (series A) and prototype of the optimal design (series B). The implant body was made of medical titanium (Grade IV). The abutment and the screw were made of medical titanium alloy (Ti-6Al-4V-ELI). The same materials were used for prototype and initial designs.

The all implants of both series (19 specimens - series A and 21 specimens - series B) have been mounted in a self-curing denture base resin Duracryl Plus (Spofa/Dental). The average mount diameter was $25.57 \mathrm{~mm}$ with an average height of $17.90 \mathrm{~mm}$ (see Fig. 3). The implants were mounted centrally with a slight offset from $90^{\circ}$ in an $\mathrm{x}-$ axis from the mount face without affecting test results. For both group
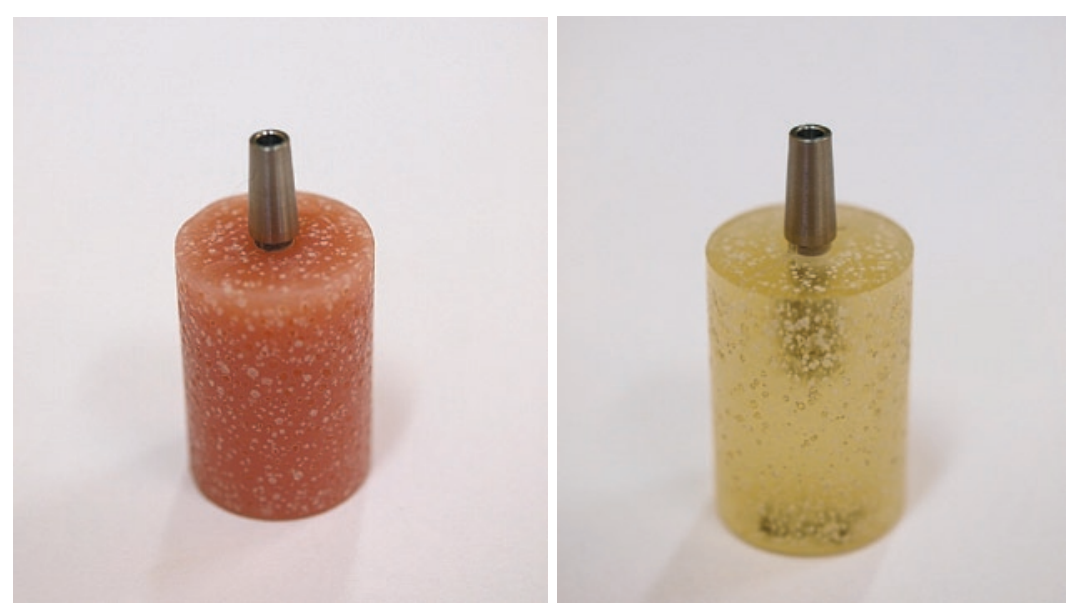
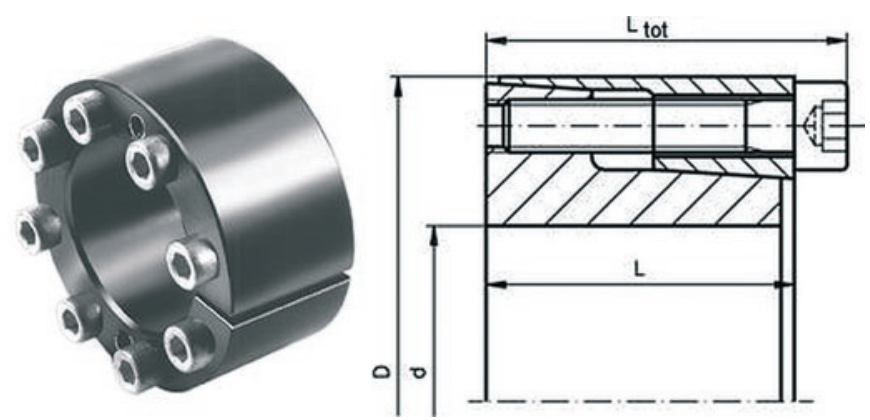

Fig. 4. Mädler 61541800 clamping set $(D=35.0 \mathrm{~mm}, d=18.0 \mathrm{~mm}$, $\left.L=21.0 \mathrm{~mm}, L_{\text {tot }}=25.0 \mathrm{~mm}\right)(\mathrm{www}$. maedler.ch $)$

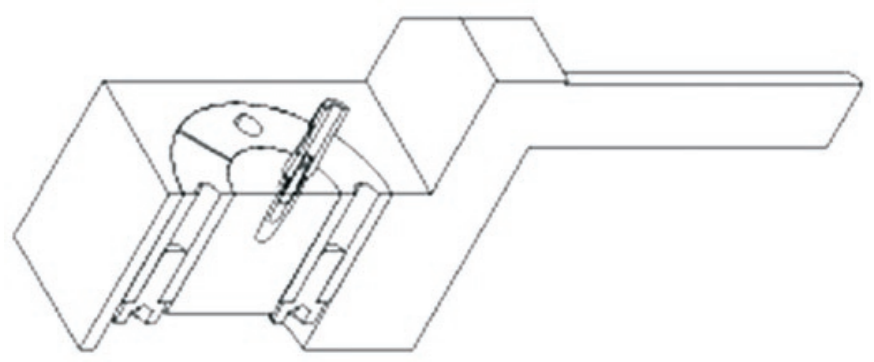

Fig. 5. Holder adapter for mounting implants on a test stand (cross-section)

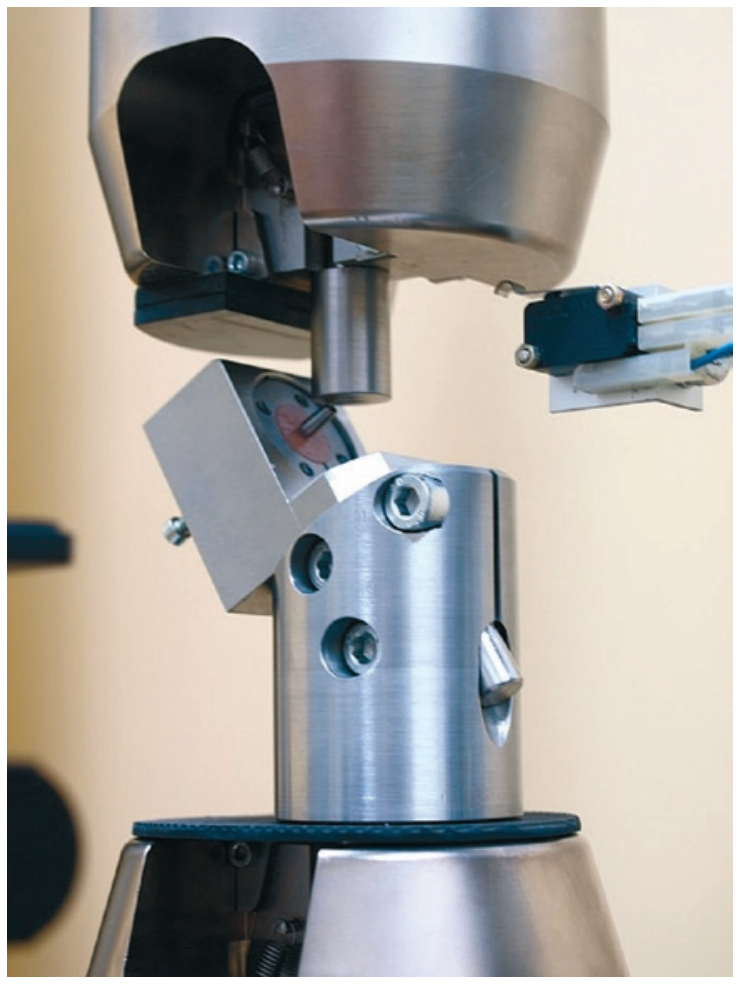

Fig. 6. Test stand according to PN-EN ISO 14801 standard clamping set with the resin cylinders with embedded implants mounted in holder of fatigue testing machine (Instron 8874)

the abutments were connected to the embedded implants and tightened to $285 \mathrm{Nmm}$ with the use of the torque control unit.

Resin cylinders with embedded implants were mounted using Mädler 61541800 clamping sets (Fig. 4) on a specially designed and made holder adapter (see Fig. 5).

Fig. 3. Dental implants prepared for testing - (a) series A, (b) series $B$ 
Table 1. The calculation results $Z_{g}$ for all specimens

\begin{tabular}{|c|c|c|c|c|c|c|c|}
\hline \multicolumn{4}{|c|}{ series A } & \multicolumn{4}{|c|}{ series B } \\
\hline specimen no. & $Z_{g}$ & specimen no. & $Z_{g}$ & specimen no. & $Z_{g}$ & specimen no. & $\mathrm{Z} \mathrm{Z} \mathrm{g}_{g}$ \\
\hline & $\mathrm{MPa}$ & & $\mathrm{MPa}$ & & $\mathrm{MPa}$ & & $\mathrm{MPa}$ \\
\hline 1 & 225.1 & 10 & 189.95 & 1 & 262.6 & 12 & 240.1 \\
\hline 2 & 175.1 & 11 & 151.6 & 2 & 226.3 & 13 & 168.1 \\
\hline 3 & 142.5 & 12 & 175.39 & 3 & 250.7 & 14 & 237.8 \\
\hline 4 & 144.76 & 13 & 142.8 & 4 & 173.8 & 15 & 227.6 \\
\hline 5 & 164.6 & 14 & 137.5 & 5 & 207.6 & 16 & 271.2 \\
\hline 6 & 234.4 & 15 & 129.6 & 6 & 249.6 & 17 & 259.4 \\
\hline 7 & 143.96 & 16 & 148.55 & 7 & 275.5 & 18 & 225.2 \\
\hline 8 & 185.8 & 17 & 142.16 & 8 & 266.2 & 19 & 243.4 \\
\hline 9 & 192.7 & - & - & 9 & 229.9 & 20 & 263.5 \\
\hline$Z_{\mathrm{mg}}$ & $\mathrm{MPa}$ & 166.26 & 10 & 215 & 21 & 208.2 & \\
\hline $\mathrm{s}_{\mathrm{Zmg}}$ & $\mathrm{MPa}$ & 30.89 & 11 & 228.1 & - & - & \\
\hline & & & & $Z_{m g}$ & $\mathrm{MPa}$ & 234.75 & \\
\hline & & & & $\mathrm{s}_{\mathrm{Zmg}}$ & $\mathrm{MPa}$ & 28.49 & \\
\hline
\end{tabular}

The fatigue tests were performed on Instron 8874 testing system using Locati method of an accelerated fatigue testing [8, 24, 40]. The Locatimethod assumes that a slope of a S-N curve is known [24].

The method uses a sinusoidally varying pulsating load with progressively-increasing amplitude. The loading method is based on ISO 14801 standard for the dynamic fatigue testing of endosseous dental implants. This standard specifies a method for determining the fatigue strength and defines the functional loading of the implant body under "worse case" conditions. The following test parameters have been set:

- loading angle equals 30 degrees from the implant axis,

- number of cycles per load stage $n=10,000$ cycles,

- minimum constant load per load stage $41-47 \mathrm{~N}$,

- load increase per load stage $0.012 \mathrm{kN}$ to $0.014 \mathrm{kN}$ for series A and $0.01 \mathrm{kN}$ for series B,

- number of cycles at the last load stage corresponds to the number of cycles at machine stop due to implant failure (see Fig. 7),

- load change frequency $5 \mathrm{~Hz}$.

Maximum bending loads were calculated as a quotient of maximum bending moment and section modulus in a position the implant mounting was initiated. The load is applied directly to the abutment. The test stand is shown in Fig. 6.

\section{Results}

A fatigue limit for each implant was calculated based on:

(i) Wöhler curve equation ( $\mathrm{S}-\mathrm{N}$ curve):

where $\sigma_{\max }$ is a maximum stress in MPa and $\mathrm{N}_{\mathrm{f}}$ is a fatigue life in number of cycles and fatigue limit for the fatigue life of
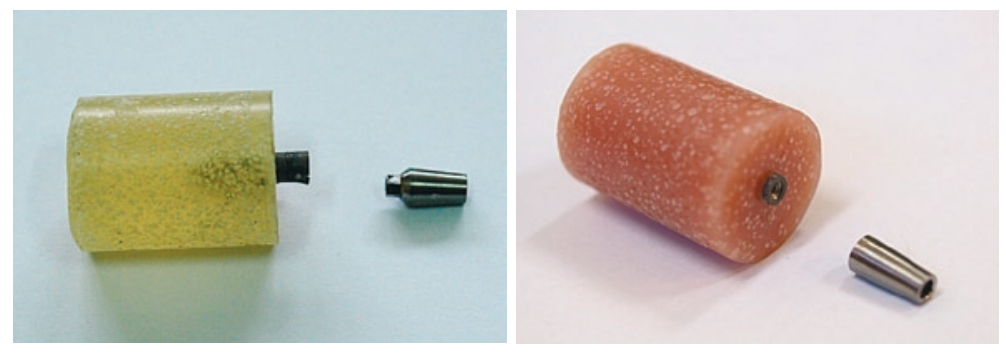

Fig. 7. Damaged implants: (a) series A; (b) series B.
$2 \times 10^{6}$ cycles was $561.72 \mathrm{MPa}$. This equation was available for ASTRA System Ti Design implants (similar to our) performed by UNIKE design\&development $\mathrm{GmbH}$, Trier,

(ii) result of experimental tests combined with the phenomenology hypothesis of cumulative fatigue damage developed by Palmgren-Miner (P-M) [24].

In accordance with the hypothesis P-M for multi-stage load at stress level $\sigma_{i}$ and $n_{i}$ fatigue cycles, the total $\Sigma n_{i} / N_{\text {fi }}$ ratio is 1 at the moment of sample failure due to fatigue. $\mathrm{N}_{\mathrm{fi}}$ for $\Sigma \mathrm{ni} / \mathrm{Nfi}$ ratio is fatigue life at load level $\sigma_{\mathrm{i}}$. This is based on the assumption that the virgin sample (load level $\sigma_{\mathrm{i}}$ and $\mathrm{n}_{\mathrm{i}}=0$ ) has a specific damage function $\mathrm{D}$ equal to 0 , and at the moment of sample failure i.e. $\mathrm{n}=\mathrm{N}_{\mathrm{f}}, \mathrm{D}=1$. The $\mathrm{n}_{\mathrm{i}} / \mathrm{Nf}_{\mathrm{i}}$ ratio for the assumed loading scheme with stepwise increasing loading $\left(\sigma_{i}, n_{i}\right.$ values are known) depends on the position of the S-N curve determined for constant amplitude loads (S-N curve) and assumed ultimate fatigue limit $\mathrm{Zg}$ corresponding to a specific fatigue life threshold, e.g. $10^{6}$ or $2 \times 10^{6}$ cycles. Last assumption is important, since it allows calculating total $\mathrm{n}_{\mathrm{i}} / \mathrm{N}_{\mathrm{fi}}$ ratio only for $\sigma_{\mathrm{i}}$ stresses $>Z_{\mathrm{g}}$.

The S-N curve position depends on the determined slope. In Locati method, with known or accepted S-N curve position (for similar to our ASTRA implants slope $=-51.674$ ), anticipated scatter is determined by a parallel up and down displacement in the coordinate axis. For the defined three $\mathrm{S}-\mathrm{N}$ curves with $\mathrm{Z}_{\mathrm{g} 1}, \mathrm{Z}_{\mathrm{g} 2}$ and $\mathrm{Z}_{\mathrm{g} 3}$, total $\Sigma \mathrm{n}_{\mathrm{i}} / \mathrm{N}_{\mathrm{fi}}$ is described as $D_{1}, D_{2}$ and $D_{3}$. Estimated fatigue limit $Z_{\mathrm{g}}$ is determined by interpolation using the linear equation or by calculation using the quadratic equation based on the initial assumption that $\mathrm{D}=1$ at sample failure.

End results - mean fatigue limit and standard deviation are:

- series A: $Z_{\mathrm{mg}}=166.26 \mathrm{MPa}, \mathrm{s}_{\mathrm{Zmg}}=30.89 \mathrm{MPa}$,

- series B: $Z_{\mathrm{mg}}=234.75 \mathrm{MPa} \mathrm{s}_{\mathrm{Zmg}}=28.49 \mathrm{MPa}$.

The damaged implant is shown in the Fig. 7. In the cases of series B the critical failure was located on the screw only. There are no damages or cracks on abutment and implant body. For series A (fig. 7b) the significant plastic deformation and cracks of hexagonal slot can be observed as well.

\section{Discussion}

The direct goal of the experimental tests is a qualitative comparison of the initial and the modified dental implant designs. However, the modifications were done based on the optimiza- 
tion strategy utilizing a new concept of hybridized genetic algorithm and finite element model.Therefore, the obtained results are also a verification of the optimization strategy and modeling methods from the viewpoint of fatigue characteristics of examined dental implant what is the main goal of this study.

The experimental test shows that used optimization approach significantly changes fatigue characteristics of the examined dental implant. The fatigue resistance is meaningly improved. The fatigue limit is increased up to $41 \%$ of the initial value. From the viewpoint of fatigue life of the implant the stress amplitude changes play the key role in this case. The changes of the stress distribution in the optimal implant design are discussed deeply by Szajek [33]. Due to new shape of horizontal fixture abutment interface and higher screw preload the effective stresses amplitude is decreased in the critical points of the screw. The stress amplitude in the screw is reduced to $3.8 \%$ of the initial value. The experimentally confirmed higher fatigue limit of optimal design is caused not only by stress amplitude reduction at hotspots but also by homogenizations of the stresses within the entire implant, higher stiffness of the preloaded structure and the negligible bending effect in the screw. It is also worth mentioning that the maximal stresses are lower despite the higher screw preload.

From the viewpoint of the general mechanics characteristic of implant system the most significant modification is the reduction of the abutment rotation and therefore screw bending. The displacement of the point where horizontal load is applied is reduced to $41 \%$ of the initial value. The abutment rotates relatively to the fixture causing screw bending which is indicated by many researchers as a main reason of fatigue fracture. $[21,23,36]$. In the initial design underging horizontal load an abutment presses strongly a top region of a fixture causing its large deformation. Moreover, the horizontal interface with larger contact region reduces circumferential tensional stresses in the fixture. The damage mechanics observed in experimental tests clearly confirmed observations and conclusions resulting from numerical modeling. In the case of initial design (series A) the significant plastic deformation are observed for both screw and hexagonal slot of fixture. In the case of optimal design (series B) the damage is located on the screw only.

\section{Conclusions}

The verification of the dental implant optimization has been done based on the experimental studies. The fatigue tests clearly show that the optimal design has significantly higher fatigue limit then the initial design.

The results from experimental investigations confirms that used optimization strategy based on finite element model and genetic algorithm hybridized with Hooke-Jeeves technique is the efficient method of an optimization for such complex nonlinear structure like dental implants. Based on the above results several general conclusions can be also confirmed or formulated.The significant fatigue resistance improvement is obtained mostly due to strong reduction of effective stress amplitude by screw bending elimination. It's caused by major changes in geometry (flat fixture abutment interface) and higher screw preload causing bigger stiffness (screw bending elimination). Due to strong interaction between geometric parameters and screw preload (screw preload depends on geometry and geometry differs for various level of screw preload) it is necessary to consider all of them in an optimization problem. The stress based approach for fatigue life calculation allows to effectively estimate fatigue life based on the ratio of effective stress amplitude at zero mean stress to a fatigue strength coefficient (Eq. 2) instead of number of fatigue cycles represented by exponential function of stresses.

The presented optimization approach is comprehensive and takes into account a several coupled mechanical and biomechanical objectives and constrains. First of all, the fatigue resistance of implant is significantly improved. At the same time the loosening and the tightening moments of the screw remain at the assumed level what is important in implantation as well as utilization stage. Too low value of loosening moment can cause need of retightening while too high value of the tightening moment can cause damage of implant-bone interface. In the modified design, the higher screw preload results in not only in the stiffness increasing and the screw loosing resistance but also better leak resistance on the fixtur eabutment interface what more efficient prevents biological complications.

\section{Acknowledgement \\ The support of Polish Ministry of Higher Education and Science under the grant R130020 06 "Development and preparation of dental implant prototypes" (Polish title: Opracowanie i przygotowanie prototypów implantów stomatologicznych") is kindly acknowledged.}

\section{References}

1. Abaqus. ABAQUS Manuals. Inc. Providence, 2005.

2. Adell R, Eriksson B, Lekholm U, Brånemark PI, Jempt T. Long-term follow-up study of osseointegrated implants in the treatment of totally edentulous jaws. International Journal of Oral and Maxillofacial Implants 1990; 5(4), 347-59.

3. Bitner JR, Ehrilich G, Reingold EM. Efficient Generation of the Binary Reflected Gray Code and Its Applications. Communications of the ACM 1976; 19(9): 517-521, https://doi.org/10.1145/360336.360343.

4. Bozkaya D, Muftu S. Mechanics of the taper integrated screwed-in (TIS) abutments used in dental implants. Journal of Biomechanics 2005; 38: 87-97, https://doi.org/10.1016/j.jbiomech.2004.03.006.

5. Casado, J. A., Carrascal, I., Polanco, J. A., Gutiérrez-Solana, F. Fatigue failure of short glass fibre reinforced PA 6.6 structural pieces for railway track fasteners. Engineering Failure Analysis, 2006; 13(2): 182-197, https://doi.org/10.1016/j.engfailanal.2005.01.016.

6. Chakrabort UK, Janikow CZ. An analysis of Gray versus binary encoding in genetic search. Information Sciences 2003; 156: 253-269, https://doi.org/10.1016/S0020-0255(03)00178-6.

7. Coray, R., Zeltner, M., Özcan, M. Fracture strength of implant abutments after fatigue testing: A systematic review and a meta-analysis. Journal of the Mechanical Behavior of Biomedical Materials 2016; 62: 333-346, https://doi.org/10.1016/j.jmbbm.2016.05.011.

8. Dengel D, Haring H. Estimation of the fatigue limit by progressively-increasing load tests 1980; (3): 113-128.

9. Flanagan D, Llies H, McCullough P, McQuoid S. Measurement of the fatigue life of mini dental implants: a pilot study. The Journal of Oral Implantology 2008; 34(1): 7-11, https://doi.org/10.1563/1548-1336(2008)34[7:MOTFLO]2.0.CO;2.

10. Freitas, A., Bonfante, E., Martins, L., Silva., N., Marotta, L., Coelho, P. Reliability and failure modes of anterior single-unit implantsupported restorations. Clinical Oral Implants Research 2012; 23(9): 1005-1008, https://doi.org/10.1111/j.1600-0501.2011.02269.x.

11. Freitas, A., Almeida, E., Bonfante, E., Silva, N., Coelho, P. Reliability and failure modes of internal conical dental implant connections. Clinical Oral Implants Research 2013; 24(2): 197-202, https://doi.org/10.1111/j.1600-0501.2012.02443.x.

12. Gargallo-Albiol, J., Satorres-Nieto, M., Puyuelo-Capablo, JL., Sánchez-Garcés, M.A., Pi-Urgell, J., G-y Escoda C. Endosseous dental implant fractures: an analysis of 21 cases. MedOralPatholOralCirBucal 2008; 13: 124-128. 
13. Gealh WC, Mazzo V, Barbi F, Camarini ET. Osseointegrated implant fracture: causes and treatment. J Oral Implantol 2011; 38:499-503, https://doi.org/10.1563/AAID-JOI-D-09-00135.1.

14. Geng JP, Tan KBC, Liu GR. Application of finite element analysis in implant dentistry: A review of the literature. Journal of Prosthetic Dentistry2001; 85: 585-598, https://doi.org/10.1067/mpr.2001.115251:

15. Genna F. On the effects of cyclic transversal forces on osseointegrated dental implants: experimental and finite element shakedown analyses. Computer Methods in Biomechanics and Biomedical Engineering 2003; 6(2): 141-152, https://doi.org/10.1080/1025584031000091696.

16. Genna F. Shakedown, self-stresses, and unilateral contact in dental implant problem. European Journal of Mechanics A/Solids 2004; 23: 485-498, https://doi.org/10.1016/j.euromechsol.2004.01.001.

17. Goldberg DE. Genetic Algorithm in Search, Optimization and Machine Learning. Addison-Wesley Professional, 1989.

18. Gunne J. Implant treatment in partially edentulous patients: a report on prostheses after 3 years. International Journal of Prosthodontics 1994; 7(2): 143-148, https://doi.org/10.1097/00008505-199412000-00014.

19. Hooke R. Jeeves TA. Direct search solution of numerical and statistical problem. Journal of Association for Computing Machinery 1961; 8: 212-229, https://doi.org/10.1145/321062.321069.

20. Ilies HT, Flanagan PT, McQuoid S. Determining the Fatigue Life of Dental Implants. Journal of Medical Devices 2008; 2(1), https://doi. org $/ 10.1115 / 1.2889058$.

21. Jörnéus L, Jemt T, Carlsson L. Loads and designs of screw joints for single crowns supported by osseointegrated implants. International Journal of Oral and Maxillofacial Implants 1992; 7(3): 353-359.

22. Jung RE, Pjetursson BE, Glauser R, Zembic A, Zwahlen M. and Lang NP. A systematic review of the 5-year survival and complication rates of implant-supported single crowns. Clinical Oral Implants Research 2008; 19(2): 119-30, https://doi.org/10.1111/j.1600-0501.2007.01453.x.

23. Khraisat A, Hishimoto A, Nomura S, Miyakawa O. Effect of lateral cycled loading on abutment screw loosening of an external hexagon implant system. Journal of Prosthetic Dentistry 2004; 91: 326-334, https://doi.org/10.1016/j.prosdent.2004.01.001.

24. Lee Y, Pan J, Hathaway R, Barkey M. Fatigue Testing and Analysis: Theory and Practice. Butterworth-Heinemann, 2011.

25. Lipski, A. Determination of Fatigue Limit by Locati Method using S-N Curve Determined by Means of Thermographic Method. Solid State Phenomena 2015, 223: 362-373, https://doi.org/10.4028/www.scientific.net/SSP.223.362.

26. Mericske-Stern R, Steilin ST, Marti P, Geering AH. Peri-implant mucosal aspects of ITI implants supporting overdentures: a five-year longitudinal study. Clinical Oral Implants Research 1994; 5(1): 9-18, https://doi.org/10.1034/j.1600-0501.1994.050102.x.

27. Onate JF.Dental abutment and implant system with conical connection. Results of fatigue resistance to compression bending, Institute of Biomechanics, Valencia, 2008.

28. Patterson EA, Johns RB. Theoretical analysis of the fatigue life of fixture screws in osseointegrated dental implants. International Journal of Oral and Maxillofacial Implants 1992; 7: 26-33.

29. Ribeiro, C., Maia, M., Scherrer, S., Cardoso, A., Wiskott, H. Resistance of three implant-abutment interfaces to fatigue testing. Journal of Applied Oral Science 2011; 19(4): 413-20, https://doi.org/10.1590/S1678-77572011005000018.

30. Simonis, P., Dufour, T., Tenenbaum. H. Long-term implant survival and success: a 10-16-year follow-up of non-submerged dental implants. Clin Oral Implants Res 2010; 21: 772-777, https://doi.org/10.1111/j.1600-0501.2010.01912.x.

31. Steinebrunner, L., Wolfart, S., Ludwig, K., Kern, M. Implant-abutment interface designaffects fatigue and fracture strengthof implants. Clinical Oral Implants Research 2008; 19: 1276-1284, https://doi.org/10.1111/j.1600-0501.2008.01581.x.

32. Strub JR, Gerds T. Fracture strength and failure mode of five different single-tooth implant-abutment combinations. International Journal of Prosthodontics 2003; 16: 167-170.

33. Szajek K. Optimization of a two-component implantology system using genetic algorithm. Poznań: Publishing House of Poznan University of Technology, 2012.

34. Szajek K, Kąkol W, Łodygowski T. and Wierszycki, M. Optimization module for Abaqus/CAE based on Genetic Algorithm. In: Proceedings of the Abaqus Users' Conference. Newport, USA,2008.

35. Szajek, K., Wierszycki, M. Numerical verification of two component dental implant in context of fatigue life for various load cases. Acta of Bioengineering and Biomechanics 2016; 18(1): 103-113.

36. Wierszycki M, Kąkol W, Łodygowski T. The screw loosening and fatigue analyses of three diemensional dental implant model. In: Proc. of the Abaqus Users' Conference 2006. Boston, 2006.

37. Wierszycki M, Kąkol W, Łodygowski T. Numerical complexity of selected biomechanical problems. Journal of Theoretical and Applied Mechanics 2006; 44: 797-818.

38. Wierszycki M. Numeryczna analiza wtyrzymałościowa wszczepów uzębienia oraz segmentu kręgosłupa ludzkiego. Poznań: Phd thesis, 2007.

39. Zagalak R. Ocena własności mechanicznych dwuczęściowych wszczepów stomatologicznych Osteoplant, Phd Thesis. Fundacja Akademii Medycznej w Poznaniu, 2003.

40. Zhang, O., Poirier, J., Barr, J. Modified Locati Method in Fatigue Testing. SAE Technical Paper 2003-01-0919, https://doi.org/10.4271/200301-0919.

\section{Krzysztof SZAJEK \\ Marcin WIERSZYCKI \\ Tomasz ŁODYGOWSKI}

Poznan University of Technology

Institute of Structural Engineering

ul. Piotrowo 5, 60-965 Poznań, Poland

\section{Tomasz TOPOLIŃSKI}

University of Technology and Life Sciences

Department of Biomedical Engineering

ul. ks. A. Kordeckiego 20, 85-225 Bydgoszcz, Poland

E-mails:krzysztof.szajek@put.poznan.pl, marcin.wierszycki@put.poznan.pl, topol@utp.edu.pl, tomasz.lodygowski@put.poznan.pl 